Risk-Return of Belgian SRI Funds

Luc Van Liedekerke, Lieven De Moor and Dieter Vanwalleghem

DEPARTMENT OF ACCOUNTANCY, FINANCE AND INSURANCE (AFI) 


\title{
Risk-Return of Belgian SRI Funds
}

\author{
Luc Van Liedekerke* \\ Katholieke Universiteit Leuven \\ Lieven De Moor ${ }^{\dagger}$ \\ European University College Brussels \\ Katholieke Universiteit Leuven \\ Dieter Vanwalleghem \\ University of Oxford
}

April 27, 2007

\begin{abstract}
We analyse the risk-return profile of Belgian SRI funds versus conventional investment funds. We apply a four-factor conditional Carhart model to establish whether there are significant differences in risk-return profile between an SRI portfolio and a conventional portfolio and test for learning effects in SRI funds. We show that there is no difference in risk-return profile between SRI and conventional funds. If return is not the problem, then what is it that limits the development of an SRI retail market in Belgium? We conclude with a short digression on this question.
\end{abstract}

Key words: SRI investment funds, risk-return analysis, Markowitz versus Moskowitz puzzle. JEL: G12

\footnotetext{
* Luc Van Liedekerke, Center for Economics and Ethics, K.U.Leuven, Naamsestraat 69, B-3000 Leuven, Belgium. Corresponding author, E-mail: luc.vanliedekerke@econ.kuleuven.be

${ }^{\dagger}$ Lieven De Moor, Centre for Economics and Management, European University College Brussels, Stormstraat 2, B-1000 Brussels, Belgium. Tel.: +32 4986164 63. Fax.: +32 221764 64. E-mail: lieven.demoor@ehsal.be

${ }^{*}$ Dieter Vanwalleghem, Vloedstraat 7, B-8800 Roeselare, Belgium. Tel.(BE): +32 4785474 43. Tel.(UK): +44 77884705 04. E-mail: dieter.vanwalleghem@ oriel.ox.ac.uk
} 


\section{Introduction}

SRI investment, sustainable investment, or Socially Responsible Investment (SRI) is a broad concept that covers many practices. According to its most general circumscription it covers every asset invested using an allocation model that takes financial as well as non-financial criteria into account. These non-financial criteria can be very diverse and range from religious criteria - respect for the God-given life was the historical basis of the SRI investment movement - to classical single issue engagement (no GMO, ban on animal testing, nuclear energy). Over the past decade the SRI movement has witnessed extensive growth in the Anglo-Saxon markets. It is now a mainstream product in the sense that it is no longer niche players who are involved in SRI but also established banks. Many banks now have at least a couple of SRI products on the shelf. The mainstreaming of SRI triggered an interest from financial economists who wanted to get a better view on SRI portfolios in comparison to the classical non-SRI portfolio. The importance of this question is further corroborated when you take a closer look at the profile of an SRI investor. While the early SRI investor was up to a great extent ideologically motivated, the modern SRI investor hardly differs from his non-SRI counterpart and is not prepared to give in on return. In a recent survey for Belgium, almost half of the participants indicated that they expected a comparable risk-return profile for the SRI investments as for their non-SRI investments. 14\% of the participants said that a lower return on investment was their main reason for staying out of SRI. And a clear majority still believes that SRI products have an inferior risk-return profile to their non-SRI counterparts. But is this the case? There exists some empirical literature on this matter, contradicting the popular view, but most of this literature concentrates on the much more established AngloSaxon market, there are hardly any serious studies for the European continent. This paper analyses data for the Belgian financial market and asks the question whether existing SRI funds are from a purely financial perspective as interesting as non-SRI funds. We start by introducing two diametrically opposed theoretical views on the risk-return profile of SRI funds. We then describe the data and our own empirical model used to answer the risk-return question. Our main result corroborates the findings for the Anglo-Saxon market: SRI funds do not differ significantly from non-SRI funds in terms of their risk-return profile. This creates another puzzle: if the financial side is not a problem, why does the retail market for SRI investments remain so small? There seem to be no fundamental financial reasons why one would not want to invest in SRI products, yet consumers still hesitate to take the step, we end with a short digression on this puzzle. 


\section{Two views on SRI investment: the Markowitz - Moskowitz debate}

During the eighties two opposing views on the financial return connected to SRI investment developed. According to the first view SRI portfolios are bound to have a higher risk-lower return profile then non-SRI portfolios (the so called eco-efficiency discount). The theoretical background for this view is the Capital Asset Pricing Model (CAPM) and the position is known as the Markowitz view after one of the founders of CAPM. CAPM is build around two variables: expected return and variance, and basically states that the only efficient portfolio is the market portfolio itself. The market portfolio is by definition the most diversified portfolio and will attain (again by definition) the highest return-variance combination. The SRI universe is always a subset of the market portfolio (you make a selection of stocks) and therefore not perfectly diversified, this implies that SRI portfolios will in the long run always have a worse return-variance result. CAPM was later on refined when Fisher [1970] and Statman [1987] demonstrated that you do not need the entire market portfolio in order to get optimal diversification, in fact a subset of 30 randomly picked shares is already sufficient to reach a degree of diversification comparable to the market portfolio. This might save SRI funds, however there is one big difference; SRI funds are not selected at random. SRI investment funds are typically biased in a number of directions: shares usually have a higher price/earnings ratio, and a higher price/book ratio. Typically you will also find that large parts of or even an entire sector is excluded from an SRI portfolio. Therefore, and despite the diversification results of Statman and Fisher, SRI portfolios will necessarily have a lower risk-return profile then the market portfolio.

Against the Markowitz/CAPM view, Moskowitz developed an opposite theoretical view which comes to the conclusion that SRI portfolios will in fact have a better risk-return profile compared to non-SRI portfolios (the so called eco-efficiency premium). His basic argument is that hidden in the SRI stock selection lies information that is not understood by the short term focus of financial markets and therefore not contained in the price of the stock. The SRI selection will according to Moskowitz be typically directed towards innovative, growthoriented companies with e.g. a well established environmental risk containment program or stable and well developed manager-employees relations. Therefore, socially responsible behaviour by a company might very well be an indicator of management competence and makes perfect economic sense. A well developed environmental management system for 
instance will in the long run decrease operational costs and taking good care of your employees raises employee motivation and thereby productivity.

All the criteria suggested by Moskowitz are typically found in SRI selection mechanisms. Looking for excellent practice in the social and environmental field forms an important part of the research by companies like EIRIS or VIGEO, and these excellent practices are in the end, according to Moskowitz, proxies for long term profit or revenue growth (Kurtz, 1997).

The Markowitz versus Moskowitz puzzle has inspired an empirical literature that is somewhat uneven in quality, but on the whole supports neither the Markowitz nor the Moskowitz position. SRI-funds typically do not differ in risk-return profile from non-SRI funds. As indicated above, there is however one serious limitation to these studies: almost all of them use American data, we have very limited empirical studies for the European continent. This article is a pilot study based on Belgian data.

\section{Data and methodology}

Our dataset contains Belgian SRI and conventional pure stock funds. All funds have at least 12 months of return data available and the research period ranges from January 1995 till December 2005. This period has the advantage that it contains a bull as well as a bear market. All data were collected through Thomson's Datastream. ${ }^{4}$ In order to identify the list of SRI funds, data is provided by Netwerk Vlaanderen, an independent NGO that follows the movement of the SRI market in Belgium. We have data on 19 Belgian SRI funds with a European focus and 28 SRI funds with a world-wide focus. At the conventional side there are 562 funds with European focus and 725 with world focus. Datastream's Total Market Europe index provided us with the market portfolio for Europe, while Datastream Total Market World index was used as a proxy for the world market portfolio.

Estimations are based on a conditional Carhart 4-factor model. ${ }^{5}$ This model is at the moment best practice when it comes to portfolio analysis. The model allows you to control for a number of variables that might explain the differences in risk-return profile between SRI and conventional funds. In fact one would like to single out the investment style of the fund in order to find the pure effect of investing in SRI versus conventional funds. Four different

\footnotetext{
${ }^{4}$ All return data were corrected for distribution of cash to fund participants and were net of transaction costs.

${ }^{5}$ Seminal work includes Fama and French (1993, 1996), Chan et al. (1996), Carhart (1997), Jegadeesh and Titman (1993), Chen and Knez (1996), Ferson and Schadt (1996).
} 
styles of investing are controlled for: playing with market exposure, concentrating on large or small caps, growth or value stock oriented investments, chasing short term winners or losers (momentum or contrarian strategies). Investment funds with different combinations of these passive investment styles generate different raw returns and these effects are singled out. ${ }^{6}$ However, a number of other factors that could influence the investment performance remain uncontrolled for, i.e. the quality of management, management fees and the quality of the SRI selection. ${ }^{7}$

More formally, the equation to be estimated is:

$$
R_{i t}-R_{f t}=\alpha_{i}+\beta_{1 i}\left(R_{M t}-R_{f t}\right)+\beta_{2 i} S M B_{t}+\beta_{3 i} H M L_{t}+\beta_{4 i} M O M_{t}+B_{i}^{\prime} Z_{t-1}\left(R_{M t}-R_{f t}\right)+\varepsilon_{i t}
$$

where

$\alpha_{i} \quad$ the estimated performance or abnormal return of fund i

$R_{i t} \quad$ the return on fund $\mathrm{i}$ in month $\mathrm{t}$

$R_{f t} \quad$ the return on a three month T-bill in month $\mathrm{t}$

$R_{M t} \quad$ the return on the equity benchmark in month $\mathrm{t}$

$S M B_{t} \quad$ the difference in return between a small cap portfolio and a large cap portfolio at time $\mathrm{t}$

$H M L_{t} \quad$ the difference in return between a portfolio of high book-to-market stocks and one of low book-to-market stocks

$\mathrm{MOM}_{t} \quad$ the difference in return between a portfolio of past 6 month winners and a portfolio of past 6 month losers at time $\mathrm{t}$

\footnotetext{
${ }^{6}$ We should stress that much of the earlier empirical work on the risk-return profile of SRI versus conventional funds did not use this type of methodology, simply because it was not available. Given the progress in financial research one can safely say that the results of many earlier studies are at best unreliable or even plainly wrong.

${ }^{7}$ To elaborate a little bit on the last variable: Ethibel, the Belgian Market leader in SRI screening distinguishes for instance between a pioneer and an excellence label. The pioneer label uses stricter selection criteria, which implies that the SRI quality of funds with a pioneer label is supposed to be higher than those with an excellence label. Those without an Ethibel label are supposed to be of even lower quality looked upon from an SRI point of view. So far our dataset is not able to estimate the impact of differences in SRI quality.
} 


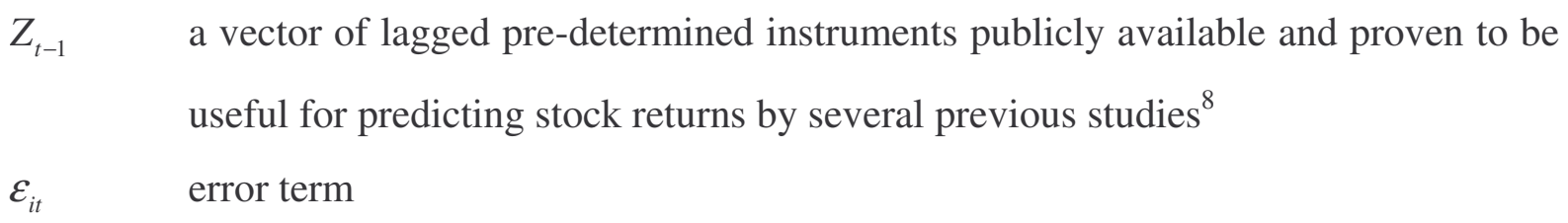

\section{Empirical results}

Table 1 shows that the null-hypothesis that SRI and conventional funds have on average the same risk-corrected return cannot be rejected. The alphas of the differential fund portfolios (long in SRI funds, short in conventional funds) are insignificantly negative, $-1.59 \%$, for the European focus; and insignificantly positive, 3.27\%, for the world focus. So there is no empirical evidence that Belgian SRI funds either under or outperform their conventional counterparts.

We do see a significant difference between SRI and conventional funds when it comes to average market sensitivity. SRI funds are less exposed to the overall market in the long run then conventional funds (steady state beta difference of -0.55 with a p-value of .001). This makes sense given the fact that SRI funds are supposed to be a non-random selected subset of the market portfolio.

Past literature (e.g. Luther \& Matatko [1994]) stressed that SRI funds tend to concentrate on small and growth oriented stocks. This should show up in significant SMB and HML coefficients for the differential fund portfolios. However, with an insignificant -0.03 and -0.04 for SMB and an insignificant 0.06 and 0.07 for HML, we cannot make the same conclusion as Luther et al.

The style analyses reveal that SRI and conventional funds actively alter their market sensitivity based on publicly available information. For both types of funds we see for example, in Table 1, significant beta timing on term structure changes. ${ }^{9}$

In Table 2 and 3 we estimated the style equation for two different time periods and two different market regimes: Jan. 1995 - Dec. 2000 (bull market, Table 2) and Jan. 2001 - Dec. 2005 (bear market, Table 3). Now we do find significant differences in risk-corrected return figures. SRI funds with world focus have a significantly higher alpha during the bull period then their conventional counterparts. (Notice a significant $+7.87 \%$ for the differential fund

\footnotetext{
${ }^{8}$ Pesaran and Timmerman (1995) discuss several studies that emphasize the predictability of returns based on interest rates and dividend yields.

${ }^{9}$ This implies further that we need a conditional Carhart model in order to control for this variable and that research not based on such a model will provide biased results.
} 
portfolio in Table 2.) ${ }^{10}$ However, both the sign as the significance level of the differential alpha disappear during the bear market. However, neither the SRI nor the conventional funds outperform the market. The SMB and HML coefficients remain insignificant in both time periods. We, therefore, again reject previous result of Luther et al. that SRI funds are biased towards small, growth oriented stocks.

Following Gregory, Matatko \& Luther [1997] we tested for learning effects in SRI funds (Table 4). According to Gregory et al. there is a positive correlation between the funds age and its financial performance, which implies that mature SRI funds should outperform emerging SRI funds. This is often explained in terms of learning effects. Although the alphas of the differential learning portfolio - long mature SRI funds and short emerging ones - are tentatively positive, we cannot reject the null-hypothesis of equal performance between mature and emerging SRI funds.

\section{Conclusion}

Turning back to the Markowitz versus Moskowitz puzzle we can conclude that Belgian SRI funds, in general, do not under nor outperform conventional funds (with just one exception). This conclusion is in line with the most recent literature and will not surprise financial economists. Although SRI portfolios are not a random subset of the market portfolio, the selection is in general sufficiently broad and diversified in order not to differ too much from the market portfolio. This implies that investors can safely turn to SRI portfolios without any serious financial risk; our only counterexample hints even towards the Moskowitz view and predicts excess returns. ${ }^{11}$ So why do we not see a massive move towards SRI investment in Europe? The European market lags far behind its American counterpart and despite strong growth the past ten years it is far from catching up. There are undoubtedly many factors involved, but it seems to us that one should not forget the supply side of the SRI market. It is only the past five years that mainstream banks have started to develop SRI products in earnest. Marketing these products is still in its infancy. One should realise that when a retail

\footnotetext{
${ }^{10}$ This result could have something to do with the SRI selection process. SRI portfolios were generally overrepresented in the high tech sector (small environmental risk, good working conditions) that gave rise to the dot.com bubble of the nineties.

${ }^{11}$ SRI funds do not differ from conventional funds in financial terms; do they differ on SRI grounds? This is a question we will not answer here, suffice it to say that when a big company like Nike starts taking ILO working conditions and human rights seriously and implements these rights in its management system, this firm will be picked up by SRI portfolios and its policy change does make a difference on the ground for many thousands of people.
} 
investor talks to her bank, most of the time this investor will follow the judgement of the banker, since he is the specialist. If the banker does not mention the SRI product and only keeps it for customers specifically asking for it, there is a big chance that the investor will never think about investing in SRI products. The communication situation and the general marketing of SRI products is at least for Belgium still underdeveloped, this also explains why the common misunderstanding that investing in SRI products equals loosing out on return is still a popular misconception among the Belgian investor. We hope that this pilot study helps eliminate some of these misconceptions altogether.

\section{References}

Bauer,R., Koedijk, K., Otten, R. [2002]. International Evidence on SRI Mutual Fund Performance and Investment Style Life. Working Paper 02.59, Maastricht University.

Carhart, M. [1997]. On Persistence in Mutual Fund Performance. Journal of Finance Vol 52, p 57-82.

Chan, L.K., Jegadeesh, N. and Lakonishok, J. [1996]. Momentum Strategies. Journal of Finance Vol 51, p 1681-1714.

Chen, Z. and Knez, P.J. [1996]. Portfolio Performance Measurement: Theory and Applications. Review of Financial Studies Vol 9, p 511-556.

diBartolomeo, D., Kurtz, L. [1999]. Managing Risk Exposures of Socially Screened Portfolios Northfield. Working Paper

Fama, E. and French, K.R. [1992]. The Cross-Section of Expected Stock Returns. Journal of Finance Vol 47, p 427-464.

Fama, E., French, K.R., 1993. Common risk factors in the returns on stocks and bonds.

Journal of Financial Economics 33, 3 - 53.

Fama, E., French, K.R., 1996. Multifactor explanations of asset pricing anomalies. Journal of Finance 51, 55- 84 .

Ferson, W. and Schadt, R. [1996]. Measuring Fund Strategy and Performance in Changing Economic Conditions. Journal of Finance, Vol. 51 p 425-562.

Fisher [1970]. Some Studies on the Variability of Return on Investment in Common Stocks, Journal of Business Vol 43, p 99-134 
Gregory, A., Matatko, J., Luther, R. [1997]. SRI unit trust financial performance: small company effects and fund size effects, Journal of Business Finance \& Accounting Vol 24 (5), p 705-724.

Grossman, B.R. and Sharpe, W.F. [1986]. Financial Implications of Divestment of South Africa- Related Stocks. Stanford Business Library

Jegadeesh, N. and Titman, S. [1993]. Returns to Buying Winners and Selling Losers : The Implications for Stock Market Efficiency. Journal of Finance Vol 48, p 65-91.

Luther, R.G. Matatko, J. and Corner D. [1992]. The Investment Performance of UK SRI Unit Trusts. Accounting, Auditing and Accountability Journal Vol 5 No 4, p 57-70.

Luther, R.G. Matatko J [1994]. The Performance of SRI Unit Trusts: Choosing an Appropriate Benchmark, Britisch Accounting Review Vol 26, p 77-89.

Pesaran, M., Timmerman, A., 1995. Predictability of stock returns: robustness and economic significance. Journal of Finance 50, 1201- 1228.

Statman [1987]. How many Stocks make a Diversified Portfolio, Journal of Financial and Quantitative Analysis Vol 22, p 353-363.

Statman, M. [2000] Socially Responsible Mutual Funds, Financial Analysts Journal May-June p 30-39 
TABLE $1 \quad$ Belgian Investment funds - Conditional 4-Factor Carhart Model

(Yearly values unless stated differently)

Period Jan 1995 - Dec 2005

\begin{tabular}{|c|c|c|c|c|c|c|c|c|c|c|c|}
\hline & 4-Factor Alpha & Market & SMB & HML & MOM & $\begin{array}{r}\text { Cond } 1 \\
\left(R_{f}\right) \\
\end{array}$ & $\begin{array}{r}\text { Cond } 2 \\
\text { (Term Structure) } \\
\end{array}$ & $\begin{array}{r}\text { Cond } 3 \\
\text { (Quality Spread) } \\
\end{array}$ & $\begin{array}{r}\text { Cond } 4 \\
\text { (Dividend Yield) } \\
\end{array}$ & $\mathrm{R}^{2} \mathrm{adj}$ & $\begin{array}{r}\text { Wald Coeff } \\
\text { (p-values) }\end{array}$ \\
\hline \multicolumn{12}{|c|}{ European focus } \\
\hline SRI & $-3.27 \%$ & 0.44 & -0.01 & 0.01 & -0.03 & -0.01 & 0.20 & -0.01 & 0.21 & 0.89 & 0.0125 \\
\hline p-values & 0.1366 & 0.0967 & 0.8963 & 0.8918 & 0.6001 & 0.8494 & 0.0235 & 0.9293 & 0.0939 & & \\
\hline Conventional & $-1.69 \%$ & 0.99 & 0.02 & -0.06 & -0.01 & -0.03 & 0.09 & -0.06 & 0.09 & 0.95 & 0.2633 \\
\hline$p$-values & 0.1888 & 0.0001 & 0.6180 & 0.1533 & 0.8957 & 0.1920 & 0.0702 & 0.4815 & 0.3200 & & \\
\hline Difference & $-1.59 \%$ & -0.55 & -0.03 & 0.06 & -0.03 & 0.02 & 0.11 & 0.05 & 0.12 & 0.15 & 0.0023 \\
\hline p-values & 0.2894 & 0.0013 & 0.4330 & 0.1753 & 0.5097 & 0.3229 & 0.0150 & 0.4376 & 0.0961 & & \\
\hline \multicolumn{12}{|c|}{ World focus } \\
\hline SRI & $-4.58 \%$ & 0.87 & 0.23 & 0.02 & -0.07 & 0.02 & 0.11 & -0.16 & 0.09 & 0.88 & 0.0071 \\
\hline p-values & 0.0772 & 0.1033 & 0.0010 & 0.7413 & 0.1404 & 0.7293 & 0.0728 & 0.3246 & 0.4519 & & \\
\hline Conventional & $-7.84 \%$ & 1.68 & 0.28 & -0.05 & -0.09 & 0.00 & 0.06 & -0.26 & -0.18 & 0.92 & 0.2566 \\
\hline p-values & 0.0037 & 0.0024 & 0.0003 & 0.3623 & 0.1171 & 0.9761 & 0.1659 & 0.1564 & 0.1008 & & \\
\hline \multirow{2}{*}{$\begin{array}{r}\text { Difference } \\
p \text {-values }\end{array}$} & $3.27 \%$ & -0.81 & -0.04 & 0.07 & 0.02 & 0.02 & 0.05 & 0.10 & 0.27 & 0.24 & 0.0192 \\
\hline & 0.2654 & 0.2493 & 0.6075 & 0.2676 & 0.7602 & 0.7933 & 0.5019 & 0.6430 & 0.0269 & & \\
\hline
\end{tabular}

Market is the return difference between the market portfolio (for Europe: Datastream's Total Market Index Europe, for the World: Datastream's Total Market Index World) and the risk-free interest rate $R_{f}$ (for Europe: 3-monthly Euribor, for the World: 3-monthly US T-Bill). SMB is the return difference between equally weighted portfolios containing the $30 \%$ smallest stocks (in terms of market capitalisation) and an equally weighted portfolio containing the $30 \%$ largest stocks. Both portfolios are re-established every year on January 1st. $H M L$ was constructed using data from the website of Kenneth French (http://mba.tuck.dartmouth.edu/pages/faculty/ken.french/) and shows the return difference between a portfolio containing high book-to-market shares and a portfolio with low book-to-market shares. $M O M$ is the return difference between equally weighted portfolios containing 30\% shares with the highest returns over the past six months and an equally weighted portfolio containing the $30 \%$ shares with the lowest return over the past six months. Following Jegadeesh \& Titman [1993] we use a six month holding period and a one-monthly time jump between the six month holding period and the six month return history. This covers the so-called bid-ask bounce i.e. the artificial negative correlation between the six month return history and the six month holding period. The MOM factor is monthly reconsidered and calculated as the average of six running MOM portfolios each starting in a different month and with an age difference from 1 to 5 months. Term Structure refers to the term structure of interest rates and more specific the difference between the yield on 10-year German government bonds and 3-monthly German government financial papers (Europe) or the difference between 10-year US bond yield and the 3-monthly US T-Bill Rate (World). Quality Spread is the difference between the long term yield on US Government Bonds (maturity > 10 year) and the long term rent of US Corporate Bonds with an A credit rating (maturity $>10$ year). 
TABLE 2 Belgian Investment funds - Conditional 4-Factor Carhart Model (Yearly values unless stated differently)

Period Jan 1995- Dec 2000

\begin{tabular}{|c|c|c|c|c|c|c|c|c|c|c|c|}
\hline & 4-Factor Alpha & Market & SMB & HML & MOM & $\begin{array}{r}\text { Cond } 1 \\
\left(\mathrm{R}_{\mathrm{f}}\right) \\
\end{array}$ & $\begin{array}{r}\text { Cond } 2 \\
\text { (Term Structure) } \\
\end{array}$ & $\begin{array}{r}\text { Cond } 3 \\
\text { (Quality Spread) } \\
\end{array}$ & $\begin{array}{r}\text { Cond } 4 \\
\text { (Dividend Yield) } \\
\end{array}$ & $\mathrm{R}^{2} \mathrm{adj}$ & $\begin{array}{r}\text { Wald Coeff } \\
\text { (p-values) }\end{array}$ \\
\hline \multicolumn{12}{|c|}{ European focus } \\
\hline SRI & $-0.84 \%$ & 1.10 & -0.03 & 0.00 & 0.02 & 0.11 & 0.26 & -0.47 & -0.02 & 0.84 & 0.0000 \\
\hline$p$-values & 0.7940 & 0.0114 & 0.7385 & 0.9621 & 0.8043 & 0.0200 & 0.0000 & 0.0038 & 0.9371 & & \\
\hline \multirow{2}{*}{$\begin{array}{l}\text { Conventional } \\
p \text {-values }\end{array}$} & $-0.35 \%$ & 1.31 & -0.02 & -0.09 & 0.02 & 0.09 & 0.13 & -0.44 & 0.05 & 0.94 & 0.0000 \\
\hline & 0.8531 & 0.0015 & 0.7502 & 0.1053 & 0.6933 & 0.0127 & 0.0092 & 0.0000 & 0.8122 & & \\
\hline \multirow{2}{*}{$\begin{array}{r}\text { Difference } \\
p \text {-values }\end{array}$} & $-0.50 \%$ & -0.21 & -0.01 & 0.09 & 0.00 & 0.01 & 0.13 & -0.03 & -0.07 & 0.19 & 0.0016 \\
\hline & 0.8187 & 0.5542 & 0.8341 & 0.1958 & 0.9462 & 0.6433 & 0.0093 & 0.7487 & 0.7120 & & \\
\hline \multicolumn{12}{|c|}{ World focus } \\
\hline \multirow{4}{*}{$\begin{array}{l}\text { SRI } \\
p \text {-values } \\
\text { Conventional } \\
p \text {-values }\end{array}$} & $-3.57 \%$ & 1.17 & 0.37 & -0.01 & -0.11 & 0.06 & 0.10 & -0.39 & -0.02 & 0.86 & 0.0010 \\
\hline & 0.2712 & 0.0602 & 0.0000 & 0.9380 & 0.0381 & 0.2787 & 0.3072 & 0.0211 & 0.9192 & & \\
\hline & $-11.44 \%$ & 1.77 & 0.34 & -0.02 & -0.12 & -0.04 & 0.24 & -0.41 & 0.15 & 0.91 & 0.1399 \\
\hline & 0.0044 & 0.0193 & 0.0024 & 0.7806 & 0.1352 & 0.4874 & 0.0223 & 0.1191 & 0.5697 & & \\
\hline \multirow{2}{*}{$\begin{array}{r}\text { Difference } \\
\text { p-values }\end{array}$} & $7.87 \%$ & -0.61 & 0.03 & 0.01 & 0.01 & 0.11 & -0.15 & 0.02 & -0.17 & 0.26 & 0.1571 \\
\hline & 0.0877 & 0.5058 & 0.8265 & 0.8426 & 0.9321 & 0.1790 & 0.2297 & 0.9369 & 0.5506 & & \\
\hline
\end{tabular}


TABEL 3 Belgian Investment funds - Conditional 4-Factor Carhart Model

(Yearly values unless stated differently)

Period Jan 2001- Dec 2005

\begin{tabular}{|c|c|c|c|c|c|c|c|c|c|c|c|}
\hline & 4-Factor Alpha & Market & SMB & HML & MOM & $\begin{array}{r}\text { Cond } 1 \\
\left(R_{f}\right)\end{array}$ & $\begin{array}{r}\text { Cond } 2 \\
\text { (Term Structure) }\end{array}$ & $\begin{array}{r}\text { Cond } 3 \\
\text { (Quality Spread) }\end{array}$ & $\begin{array}{r}\text { Cond } 4 \\
\text { (Dividend Yield) }\end{array}$ & $\mathrm{R}^{2} \mathrm{adj}$ & $\begin{array}{r}\text { Wald Coeff } \\
\text { (p-values) }\end{array}$ \\
\hline \multicolumn{12}{|c|}{ European focus } \\
\hline \multirow{4}{*}{$\begin{array}{l}\text { SRI } \\
p \text {-values } \\
\text { Conventional } \\
\text { p-values }\end{array}$} & $-7.15 \%$ & 1.09 & 0.02 & 0.02 & 0.06 & -0.21 & -0.27 & 0.17 & 0.35 & 0.95 & 0.0002 \\
\hline & 0.0378 & 0.0358 & 0.8463 & 0.7503 & 0.5081 & 0.0273 & 0.0195 & 0.2067 & 0.0405 & & \\
\hline & $-4.06 \%$ & 1.09 & 0.11 & -0.03 & 0.00 & -0.11 & -0.12 & 0.10 & 0.12 & 0.98 & 0.0110 \\
\hline & 0.0285 & 0.0203 & 0.0833 & 0.4737 & 0.9509 & 0.1584 & 0.0907 & 0.3665 & 0.3014 & & \\
\hline \multirow{2}{*}{$\begin{array}{r}\text { Difference } \\
\text { p-values }\end{array}$} & $-3.09 \%$ & 0.00 & -0.08 & 0.05 & 0.06 & -0.10 & -0.15 & 0.07 & 0.23 & 0.19 & 0.0425 \\
\hline & 0.1827 & 0.9962 & 0.2125 & 0.2815 & 0.3369 & 0.1953 & 0.0514 & 0.5335 & 0.0816 & & \\
\hline \multicolumn{12}{|c|}{ World focus } \\
\hline \multirow{4}{*}{$\begin{array}{l}\text { SRI } \\
\text { p-values } \\
\text { Conventional } \\
p \text {-values }\end{array}$} & $-4.14 \%$ & 1.38 & -0.01 & 0.12 & 0.03 & -0.17 & -0.12 & -0.01 & 0.18 & 0.93 & 0.0006 \\
\hline & 0.2228 & 0.2089 & 0.8530 & 0.2623 & 0.7645 & 0.1919 & 0.3720 & 0.9709 & 0.2597 & & \\
\hline & $-3.46 \%$ & 2.15 & 0.13 & -0.10 & -0.05 & -0.14 & -0.12 & -0.16 & -0.15 & 0.96 & 0.4406 \\
\hline & 0.1855 & 0.0759 & 0.0807 & 0.1038 & 0.5461 & 0.3372 & 0.3648 & 0.5952 & 0.1587 & & \\
\hline \multirow{2}{*}{$\begin{array}{r}\text { Difference } \\
p \text {-values }\end{array}$} & $-0.68 \%$ & -0.77 & -0.14 & 0.22 & 0.08 & -0.04 & 0.00 & 0.15 & 0.33 & 0.32 & 0.0033 \\
\hline & 0.7943 & 0.6018 & 0.0980 & 0.0508 & 0.4605 & 0.8303 & 0.9858 & 0.7004 & 0.0122 & & \\
\hline
\end{tabular}


TABEL 4 Belgian Investment funds: Mature versus Emerging SRI Funds

(Yearly values unless stated differently)

\begin{tabular}{|c|c|c|c|c|c|c|c|c|c|c|c|}
\hline \multicolumn{12}{|c|}{ Period Jan 2001- Dec 2005} \\
\hline & 4-Factor Alpha & Market & SMB & HML & MOM & $\begin{array}{r}\text { Cond } 1 \\
\left(R_{f}\right)\end{array}$ & $\begin{array}{r}\text { Cond } 2 \\
\text { (Term Structure) }\end{array}$ & $\begin{array}{r}\text { Cond } 3 \\
\text { (Quality Spread) }\end{array}$ & $\begin{array}{r}\text { Cond } 4 \\
\text { (Dividend Yield) }\end{array}$ & $\mathrm{R}^{2} \mathrm{adj}$ & $\begin{array}{r}\text { Wald Coeff } \\
\text { (p-values) }\end{array}$ \\
\hline \multicolumn{12}{|c|}{ European focus } \\
\hline \multirow{2}{*}{$\begin{array}{l}\text { Difference } \\
p \text {-values }\end{array}$} & $0.24 \%$ & 0.08 & 0.04 & -0.05 & -0.02 & -0.04 & 0.00 & 0.03 & -0.02 & \multirow[t]{2}{*}{-0.07} & \multirow[t]{2}{*}{0.6571} \\
\hline & 0.8950 & 0.8527 & 0.5276 & 0.3482 & 0.7586 & 0.6408 & 0.9729 & 0.8166 & 0.8835 & & \\
\hline \multicolumn{12}{|c|}{ World focus } \\
\hline \multirow{2}{*}{$\begin{array}{l}\text { Difference } \\
p \text {-values }\end{array}$} & $1.38 \%$ & 1.79 & -0.03 & -0.13 & -0.04 & -0.08 & -0.08 & -0.48 & -0.29 & \multirow[t]{2}{*}{0.13} & \multirow[t]{2}{*}{0.0521} \\
\hline & 0.6890 & 0.2089 & 0.7917 & 0.2327 & 0.7643 & 0.6600 & 0.6454 & 0.1424 & 0.0997 & & \\
\hline
\end{tabular}

To define mature versus emerging SRI funds we used January 1, 2001 as cut-off date. 